論文

\title{
光合成セラミクス素子の概念とその実現性に関する 素材文化学的研究
}

\author{
Materials Culturology Discussions on The Concept of Photosynthesis Ceramics \\ Element and Its Feasibility \\ by
}

Kazutaka MAKino

In this paper, in order to establish a new engineering field based on the comprehensive knowledge of humanities and science, the food crisis of human beings in the near future has been taken into notice and discussed from a point of materials culturology. As a result, it has been pointed out the food crisis to be one of short term \& serious problems. And, to overcome the food crisis in the near future, new concept of artificial photosynthesis system supporting the food poroblem of human beings has been conceptually presented. And the feasibility has been fundamentally discussed from points of materials engineering and materials culturology.

The following results has been obtained.

1) The photosynthesis mechanism of green plant was discussed from a point of materials engineering, and five conditions necessary to realize the photosynthesis are fandamentally elucidated.

2) The five conditions of 1 ) were shown to be satisfied by intoroducing the concept or $\Phi / 1-\Phi$ type of pn-conjunction particle.

3) The optimum combination of photosynthesis catalysis was pointed to be AIN, $\mathrm{SrTiO}_{3}, \mathrm{Sr}_{0.75} \mathrm{Ag}_{0.25} \mathrm{TiO}_{3}, \mathrm{GaSe}, \mathrm{GaTe}, \mathrm{SnS}$. And each photosynthesis catalysis was quantitavely designed into $\Phi / 1-\Phi$ type of pn-conjunction particle.

4) New two concepts of photosynthesis ceramics element and photosynthesis system, necessary to photosynthesize glucide from $\mathrm{CO}_{2}, \mathrm{H}_{2} \mathrm{O}$ and the sunlight, were presented.

5) The area of the leaflike plane of photosynthesis system, necessary to synthesize the per capita daily consumption of glucide $250 \mathrm{~g}$, was pointed out to be $1.2 \mathrm{~m}^{2}$.

Key words : Photosyntheis Ceramics, Photosynthesis Catalysis, Photosynthesis

\section{平成 9 年 10 月 2 日受付}

秋田大学鉱山学部 資源・素材工学科 $\overline{\mathbf{T}} 010$ 秋田市手形学園町 1-1

Dept. of Materials Engineering for Resources, Mining College, Akita University $\mathbf{T} 010$ 1-1, Tegatagakuencho, Akita, Japan 


\section{はじめに}

科学技術は科学㧍よび技術の総称であり, 科学は自 然認識の体系であり, 技術は生産手段における客観性 ある知識体系である。17世紀デカルト ${ }^{1)}$ は科学の方法 に関して

1）精神に明晰判明なもののみを真と認め, 速断や 先入見を排除するという明証性の規則。

2）問題を出来るだけ多くの小さい部分に分けてあっ とも単純で認識しやすい要素を見出すという分析の規 則

3）最も単純なむのから最も複雑なものへ思考を順 序正しく導くという総合の規則

4）見落としがないかどうか十分に再検討するとい う枚挙の規則

の 4 つの手法を提案した。

19世紀中葉ミル ${ }^{2)}$ は帰納的方法論を重視した。以来, 科学の方法は本質的には経験からの帰納であると云わ れてきた。しかしながら, 現代諸科学は単に䚻納法に より構築されると見ることは不可能で, 近年では仮設 演繹法が科学方法論の基本的形態であると一般に評価 されるようになった。

以上のことは生産手段における客観性ある知識体系 である技術開発についても同様に云うことができる。 しかしながら，埽納的にしろ演繹的にしろ技術が客観 性ある専門知識体系を追求するあまり，技術がいかに 役立ちいかなる影響をおよぼすかについての考察がな おざりにされる傾向を生じてきた。つまり，技術の理 系的知識が重視され，技術の人文系的知識は疎んじら れ, 本来の “文化としての技術” が徐々に “企業利益 としての技術” へと変質させられてきた。このことが 企業の理系指向之文明の理系離れ之いう双極化現象を 惹起せしめていると指摘できる。近年の青少年の理系 離れはその顕在化の 1 つの表われであると見ることが できる。

鳥のように空を飛んだりチーターのように颯爽と走っ たりできれば人間の生活空間が量的にも質的にも著し く向上すると “ある人間”が考える。つまり，まず技 術の価值が人文系的考察により創造される。こうして 動機づけられ， 1 人は 2 人になり 2 人は 3 人となり, 人々は献身的に理系的考察を行ない, 長期間を費やし, ついに飛行機や自動車の開発に成功する。そして，素
材文明の新局面の主人公として空を飛び，地上を走り 迴り今日に至っている。ここに技術に打ける人文系的 知識と理系的知識との本来の不可分の関係を見ること ができる。

しかしながら，専門分化が進展し，企業文明がその あるべき状態から理系指向へと傾斜し，人文系を疎ん じるにつれ “企業利益優先”という単一な価值基準が 他の価值基準を駆逐しつつあり，一方，これに対抗し て素材文明が理系離れを起こしつつある。

以上のことは技術に豊かな価值を復活させるために 人文系と理系の総合的知識に立脚した新しい “工学” という学問体系を構築する必要があることを意味して いる。

国連食糧農業機関（FAO）によれば ${ }^{3)}$ 1974〜 76年 4 億3,500万人いる世界の栄養不足人口が, 2,000 年になっ ても減少しないむのと予測されている。これは世界の 食糧生産量そのものの絶対的不足（理系的課題）とい うよりむしろ先進国と途上国間での食糧分配の偏り (人文系的課題) の結果であると考えられている。先 進国と途上国間の食糧分配の偏りが是正されれば世界 の栄養不足人口が消失するという認識である。このよ うな状況の中で生まれたのが食糧過㮃という先進国の 農業問題である。

このことが先進国の食糧問題は存在しないことを意 味するのであろうか。

1974〜76年の世界の農用地は50億ha で, 陸地総面 積の30数\%を占めているが，その拡張は工業的開発に 圧迫され容易ではない。また，世界人口は2,025年に は82億人（1990年50億人）となり,一人あたりの食糧 需要の增加屯見込まれている。かりに一人あたりの食 糧需要が現在のままで一定に保たれかつ先進国と途上 国間の食糧分配の偏りが是正されるというドラスティッ クな仮定が満たされるとしても, 穀物類, ジャガイモ, サッマイモ, 大豆, 砂糖などの食糧生産量は2,025年 には現在の1.8倍を達成しなければならない。つまり， 人類は先進国の食糧過剩と途上国の食糧不足という問 題を抱えながら，ここ30年以内に少なくとも食糧生産 量を現在の1.8倍に増大させなければならない。

食糧問題は資源・エネルギー問題, 地球環境問題の ように, 100 年, 1,000 年の計としての課題である。し かし人類にとっていまや食糧問題は 30 年課題として顕 在化していると指摘できる。 
つまり先進国の食糧問題は切迫した緊急課題である。

この克服には, 次の 2 点すなわち 1 つは食糧分配の 偏りの是正そして他の 1 つは農用地の拡張と生産力の 増大が必要である。ここでかりに，前述のように前者 が解決されても後者は依然として “食糧生産量を30年 内に1.8倍にする”という課題を残す。そして，この 克服は基本的には農用地の拡張に依存し厳しい状況に ある。

このことは農用地による食糧生産システムとは別の 支援システムとしての食糧生産の技術システムの開発 が重要な技術的課題となることを意味している。それ は人類の食糧問題を量的にも質的にも著しく安定状態 へと変革するものと考元られる。

本報では，以上の観点から，緑色植物が太陽光，二 酸化炭素および水から有機化合物 $\left(\mathrm{CH}_{2} \mathrm{O}\right)_{\mathrm{n}}$ を合成す る光合成メカニズムを模倣し, 太陽光, 二酸化炭素扝 よび水から有機化合物 $\left(\mathrm{CH}_{2} \mathrm{O}\right)_{\mathrm{n}}$ を合成する光合成セ ラミクス素子の概念を提出し, その実現可能性につい て素材物性学的ならびに素材文化学的に考察する。

\section{1. 植物の光合成メカニズムについて}

\section{1 植物の光合成の進化と発見について}

35億年から 40 億年前地球上に生命が誕生した。その 頃大気は稀薄で, 主にメタン, 炭酸ガスおよび水蒸気 からなっていた。酸素は, 地球上に存在する物質の酸 化（あるいは燃焼）のため使用され尽し，大気中には 存在しなかった。

地上には水があった。岩から栄養分を吸収した水が 水たまりに集まる。水が蒸発するにつれて, 栄養分が 濃縮され豊かなスープが水たまりにできる。最初の生 物はこのスープを食料源とし，それを呼吸作用により 水と二酸化炭素に分解しながら消費した。こうして生 命が成長するにつれて，自らの組織と機能の維持のた め食し消費する欲求が生まれ, 多少複雑な化合物を再 合成するようになった。そして，小さな分子から大き な分子を合成するのに太陽エネルギーを使用する生物 が現われた（緑色植物，藻類，紅色拉よび緑色硫黄細 菌など)。また，太陽光エネルギー以外の他の還元力 を有する物質を用いて小さな分子から大きな分子を合 成することを学んだ生物も現われた（硫黄細菌, 硝化 細菌，水素細菌，鉄細菌など)。これらの生物のよう に生命の建築用ブロックのつくり方を知っているつま
り無機物のみの栄養で生活増殖する生物のことを自主 栄養生物という。以上は植物の光合成の進化の概略で ある。

1780年イギリスの神学者, 哲学者, 化学者, 植物生 理学者プリーストリー- ${ }^{4)}$ はローソクとハッカネズミを 用いた実験より緑色植物や藻の細胞が光を受けて酸素 を発生することを見出した。1786年オランダの医師, 植物生理学者インゲンホウス ${ }^{5)}$ はプリーストリーの実 験を繰返し，植物の炭酸同化作用および吸収作用を発 見した。

1796年スイスの牧師スヌビエは植物において酸素が 発生するには二酸化炭素の存在が必要であることを示 した。また，同時期にスイスの植物生理学者ソシュー ルは植物に出入れする物質の定量的研究を初めて行っ た。そして，窒素化合物が根から吸収されること，お よび植物体内で二酸化炭素と水が結合することを見出 した。また，植物のガス交換について定量的実験を行 い, 放出される酸素之吸収される二酸化炭素の量は等 しく, 二酸化炭素の分解之吸収の結果として植物の重 量が増加することを示した。その結果次式の光合成の 基本反応が明らかにされた。

$$
n \mathrm{CO}_{2}+n \mathrm{H}_{2} \mathrm{O}+\text { 光エネルギー } \rightarrow\left(\mathrm{CH}_{2} \mathrm{O}\right)_{n}+n \mathrm{O}_{2}
$$

(1)

\section{2 植物の光合成メカニズムとその熱物理学的条 件について}

緑色植物の光合成は Fig. 1 亿示す $5 つ$ の応すな

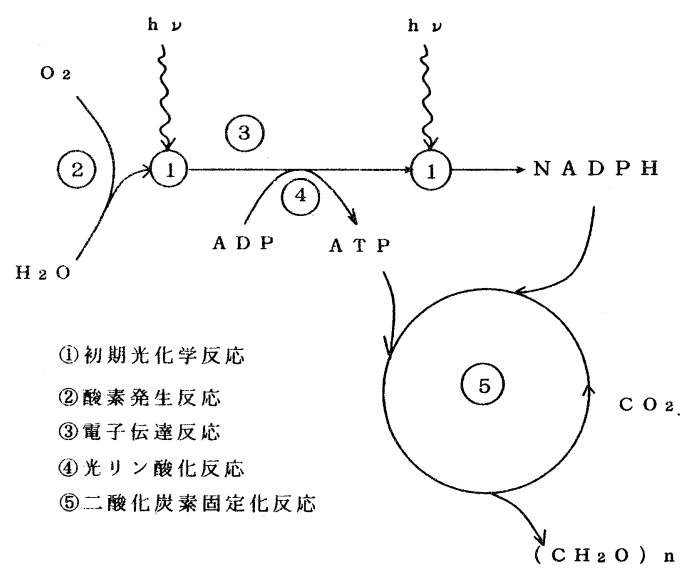

Fig. 1 Five fundamental reactions consutructing the photosynthesis of green plant (1) (4) ; light reaction, (5); dark reaction) 
わち, (1)初期光化学反応, (2)酸素発生反応, (3)電子伝 達反応，(4)光リン酸化反応および(5)二酸化炭素固定反 応 から成り立っている。このうち(1)〜 (4)は明反応と 呼ばれ後述の暗反応に必要なエネルギーと物質をつく りだす。一方，(5)は暗反応と呼ばれ明反応から供給さ れるエネルギーと物質を用いて二酸化炭素と水をブド ウ糖へと変換する。

\section{2.1 植物の光合成における明反応について ${ }^{6) \sim 10}$}

植物の光合成における明反応は葉緑体のチラコイド 膜に局在する。Fig. 2 にはチラコイドメンブレンにお ける明反応の概念図を示してある。これによれば明反 応は光学系 1 (PS 1) と光学系 2(PS 2) から構成さ れていることがわかる。

チコライドメンブレンに光が照射すると, 二つの光

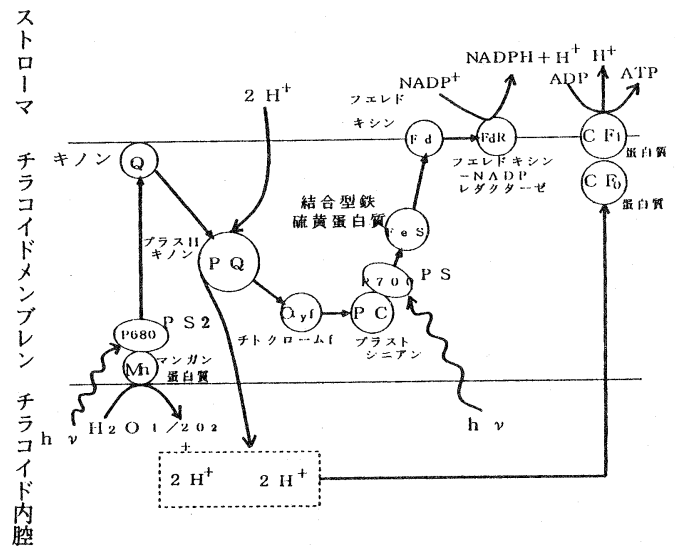

Fig. 2 The concept of light reaction in thylakoid membrane

(Photosynthesis PS1 and PS2)

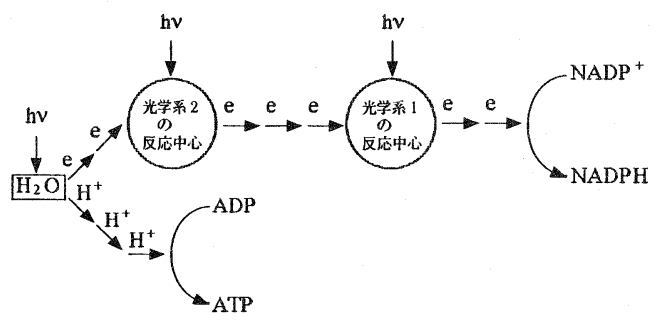

Fig. 3 Two kinds of role of light reaction in the photosynthesis of green plant

- Production of a material for fixing carbon dioxide and a energy source driving photosynthesis reaction-
学系が励起される。光学系 2 は水 $\mathrm{H}_{2} \mathrm{O}$ から電子を受 けとり, その電子は種々の電子伝達体の間を運ばれ, 光学系 1 により $\mathrm{NADP}^{+}$に渡される。同時にこの電子 伝達系に共役して ADP とオルトリン酸から ATP が 生成される (光リン酸化)。この明反応によって得ら れた NADPH は $\mathrm{CO}_{2}$ の還元剤（固定剤）として，ま たATPはエネルギー源として使用される。

水 $\mathrm{H}_{2} \mathrm{O}$ から得られた電子が $\mathrm{NADP}^{+}$まで移動する 間の電子伝達系構成成分としては Fig. 2 からもわか るようにマンガン蛋白質 $(\mathrm{Mn})$, 結合型プラストキ, ン $(\mathrm{Q}, \mathrm{PQ})$, チトクローム $\mathrm{f}(\mathrm{Cytf})$, プラストシニ アン $(\mathrm{PC})$, 結合型鉄硫黄蛋白質 $(\mathrm{FeS})$, フェレドキ

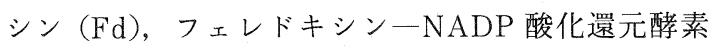
などである。そして光学系 1(P 700) と光学 2(P 680) は蛋白質之結合した特別の葉緑素である。

以上からわかるように明反応では太陽光エネルギー を用いて水 $\mathrm{H}_{2} \mathrm{O}$ より電子をとりだし，その電子によ り $\mathrm{NADP}^{+}$を $\mathrm{NADPH}$ へ還元することおよびこの 還元反応に共役して水 $\mathrm{H}_{2} \mathrm{O}$ より得た水素イオン $\mathrm{H}^{+}$に より ADP とオルトリン酸から ATP へとリン酸化す ることの 2 つ仕事がなされる。そしてNADPH は $\mathrm{CO}_{2}$ 固定のための原料の 1 つとして, ATP はエネル ギー源として暗反応部へと送り込まれる。

Fig. 3 には植物の光合成における明反応の 2 つの役 割を概念的に示してある。

1. 2.2 植物の光合成における暗反応について ${ }^{11) \sim 17)}$ 一カルビンーベンソンサイクルー

前節の明反応でつくられた $\mathrm{CO}_{2}$ 固定化用原料の 1 つである NADPH ならびに $\mathrm{CO}_{2}$ 固定化反応のエネル ギー源である ATP を用いて $\mathrm{CO}_{2}$ を固定化するサイク ルが暗反応である。この暗反応はカルビンーベンソン サイクルと呼ばれる。

Fig. 4 には暗反応のカルビンーベンソンサイクル の概念図を示してある。なお, 図中 6,12 などの数字 は分子数を， $3 \mathrm{C}, 5 \mathrm{C}$ などの記号は分子に含まれる 炭素数を意味している。これによればカルビン一べ ンソンサイクルは出発原材料リブロースー 5 -リン酸 （Ru5p）にATP を作用させてリブロースー1，5二リン酸 $(\mathrm{RuBP})$ にし，その $\mathrm{RuBP}$ と二酸化炭素と から 3 -ホスホグリセリン酸（PGA）に変換する。 そして,このPGAにATPを作用させホスホリルホ スホグリセリン酸 (HHG) とし，これと NADPH と 


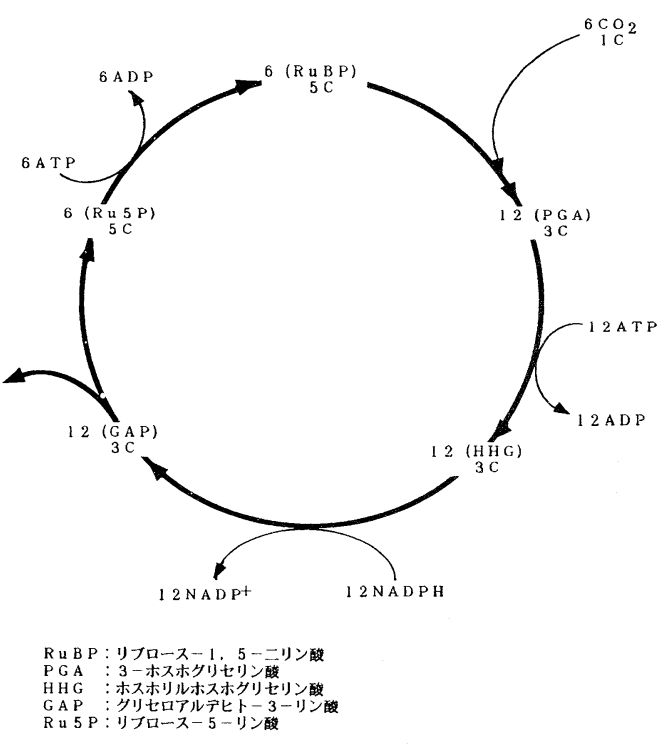

Fig. 4 The concept diagram of Calvin Benson Cycle (Dark reaction) (No.1)
からグリセロアルデヒトー3ーリン酸（GAP）を合 成する。こうして合成された GAP の 6 分の 5 が再び 同一量の出発原材料 Ru $5 \mathrm{P}$ となり, 残りの 6 分の 1 が 二酸化炭素固定分としてのブドウ糖となる。つまり， カルビンーベンソンサイクルとは出発原材料 Ru $5 \mathrm{P}$ を ATP および NADPH を用いて生成物の 6 分の 5 を循環させ， 6 分の 1 を系外に排出するという特徵を 有している。

カルビンーベンソンサイクルをさらに詳細に記述す ればFig. 5 のようになる。これによれば前述の特徴 がさらに明瞭となることがわかる。すなわち， $6 \mathrm{CO}_{2}$ (炭素数 1) が $6 \mathrm{Ru} 5 \mathrm{P}$ (炭素数 5 ) に受け取られて 12 GAP（炭素数 3) ができる。このうち 10GAP はむう 一度元通の 6Ru5P をつくるのに用いられ，正味の残 として 1 分子の GAP が系外に排出される二酸化炭素 の固定分となる。

以上より，植物の光合成の明反応および暗反応にお いてつぎのような化学反応が生じていることが指摘で きる。
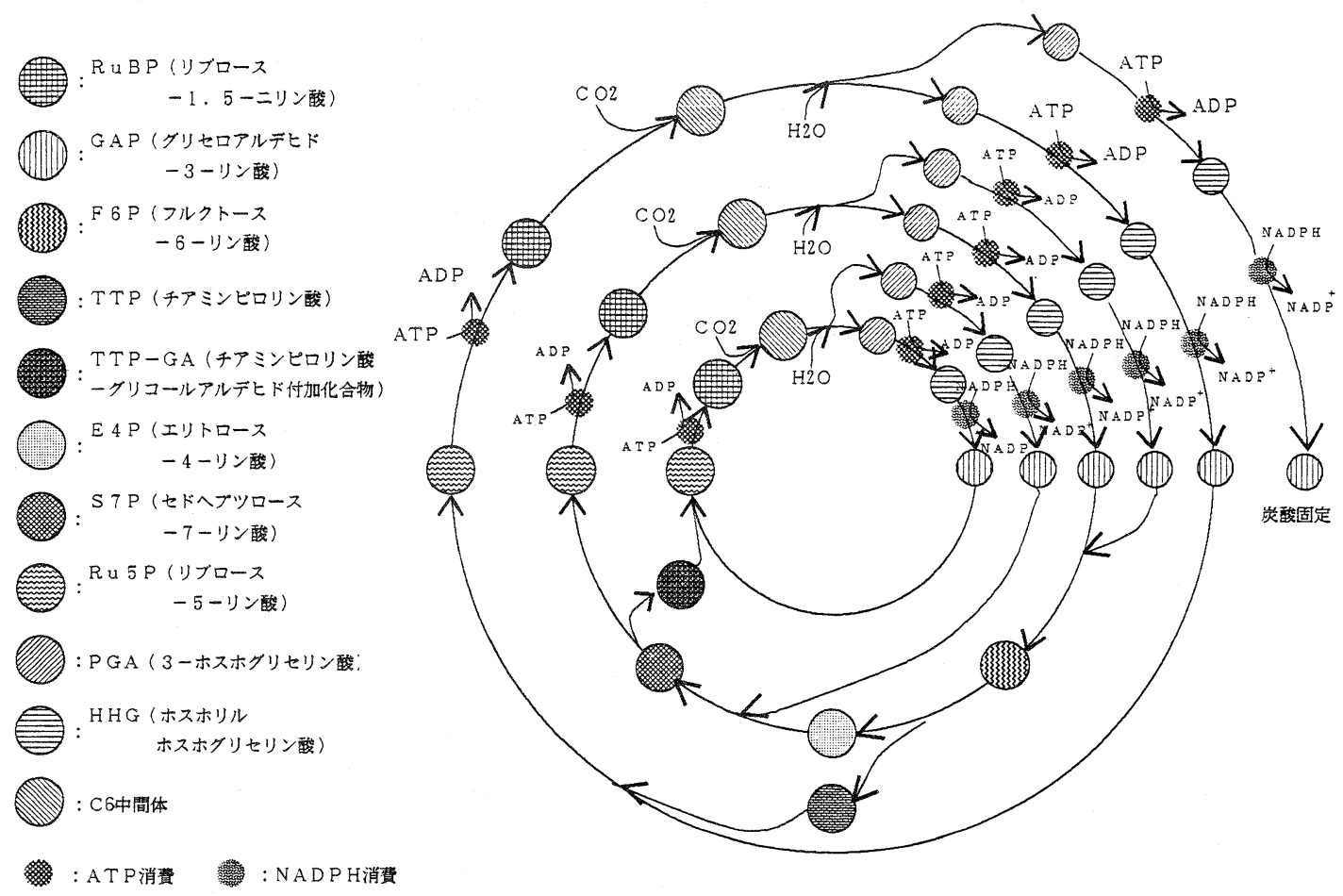

Fig. 5 The concept diagram of Calvin Benson Cycle (Dark reaction) (No. 2) 
明反応（チコライドメンブレン，ストローマ・チラ コイドメンブレン界面およびチラコイドメンブレン) $\mathrm{H}_{2} \mathrm{O} \rightarrow 2 \mathrm{H}^{+}+1 / 2 \mathrm{O}_{2}$

$3 \mathrm{ADP}+3 \mathrm{Pi}+3 \mathrm{H}^{+} \rightarrow 3 \mathrm{ATP}+3 \mathrm{H}_{2} \mathrm{O}$ $\triangle \mathrm{G}=0.33 \mathrm{eV}$

$2 \mathrm{NADP}+2 \mathrm{H}_{2} \mathrm{O} \rightarrow 2 \mathrm{NADPH}+1 / 2 \mathrm{O}_{2}+2 \mathrm{H}^{+}$

$$
\triangle \mathrm{G}=2.29 \mathrm{eV}
$$

暗反応 (カルビンーベンソンサイクル)（ストローマ内）

$\mathrm{Ru} 5 \mathrm{P}+\mathrm{ATP} \rightarrow \mathrm{RuBP}+\mathrm{DP} \quad \triangle \mathrm{G}=0.23 \mathrm{eV}$

$\mathrm{RuBP}+\mathrm{CO}_{2} \rightarrow \mathrm{C}_{6}$ 中間体 $(2$-カルボキシルー3ケトリビトール $-1,5$ ビスリン酸)

$\mathrm{C}_{6}$ 中間体 $+\mathrm{H}_{2} \mathrm{O} \rightarrow 2 \mathrm{PGA}$

$2 \mathrm{PGA}+2 \mathrm{ATP} \rightarrow 2 \mathrm{HHG}+2 \mathrm{ADP} \quad \triangle \mathrm{G}=0.19 \mathrm{eV}(8)$ $2 \mathrm{HHG}+2 \mathrm{NADPH} \rightarrow 2 \mathrm{GAP}+2 \mathrm{NADP}+2 \mathrm{Pi}$

$1 / 3 \mathrm{GAP}+1 / 3 \mathrm{H}^{+} \rightarrow 1 / 3\left(\mathrm{CH}_{2} \mathrm{O}\right)_{3}+1 / 3 \mathrm{Pi}$

$1 / 3 \mathrm{GAP}+1 / 3 \mathrm{GAP}+1 / 3 \mathrm{H}^{+} \rightarrow 1 / 3 \mathrm{~F} 6 \mathrm{P}+1 / 3 \mathrm{Pi}$

$1 / 3 \mathrm{~F} 6 \mathrm{P}+1 / 3 \mathrm{TPP}+1 / 3 \mathrm{H}^{+} \rightarrow 1 / 3 \mathrm{E} 4 \mathrm{P}+1 / 3 \mathrm{TPP}-\mathrm{GA}$ (12)

$1 / 3 \mathrm{GAP}+1 / 3 \mathrm{E} 4 \mathrm{P}+1 / 3 \mathrm{H}^{+} \rightarrow 1 / 3 \mathrm{~S} 7 \mathrm{P}+1 / 3 \mathrm{Pi}$

$1 / 3 \mathrm{GAP}+1 / 3 \mathrm{TPP}-\mathrm{GA} \rightarrow 1 / 3 \mathrm{Ru} 5 \mathrm{P}+1 / 3 \mathrm{TPP}+1 / 3 \mathrm{H}^{+}$

(14)

$1 / 3 \mathrm{~S} 7 \mathrm{P}+1 / 3 \mathrm{TPP}+1 / 3 \mathrm{H}^{+} \rightarrow 1 / 3 \mathrm{Ru} 5 \mathrm{P}+1 / 3 \mathrm{TPP}-\mathrm{GA}(15)$ $1 / 3 \mathrm{TPP}-\mathrm{GA}+1 / 3 \mathrm{GAP} \rightarrow 1 / 3 \mathrm{Ru} 5 \mathrm{P}+1 / 3 \mathrm{TPP}+1 / 3 \mathrm{H}^{+}$

(16)

$1 / 6\left(\mathrm{CH}_{2} \mathrm{O}\right)+1 / 6\left(\mathrm{CH}_{2} \mathrm{O}\right)_{3} \rightarrow 1 / 6\left(\mathrm{CH}_{2} \mathrm{O}\right)_{6}$

$1 / 6 \mathrm{n}\left(\mathrm{CH}_{2} \mathrm{O}\right)_{3_{\mathrm{n}}}+1 / 6 \mathrm{n}\left(\mathrm{CH}_{2} \mathrm{O}\right)_{3} \rightarrow 1 / 6_{\mathrm{n}}\left(\mathrm{CH}_{2} \mathrm{O}\right)_{6_{\mathrm{n}}} \quad$ (18) 結局, 明反応と暗反応により次の反応が生じている ことがわかる。

$\mathrm{CO}_{2}+\mathrm{H}_{2} \mathrm{O} \rightarrow(1 / 6 \mathrm{n})\left(\mathrm{CH}_{2} \mathrm{O}\right)_{6 \mathrm{n}}+\mathrm{O}_{2}$

ここで, $\left(\mathrm{CH}_{2} \mathrm{O}\right)_{6_{\mathrm{n}}}$ が二酸化炭素固定分としてのブド ウ糖である。

式(2)から式(19)の反応サイクルは1分子のリブロースー 5 - リン酸 Ru5P，3 分子のアデノシン 5'-ミリン酸 $\mathrm{ATP}, 3$ 分子の正リン酸 Pi および 2 分子の還元型二 コチン酸アミドアデニンジヌクレオチドリン酸NADPH を出発原料として循環させて達成される。そしてこの

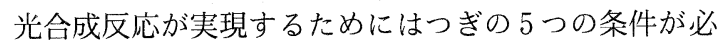
要であると指摘できる。

(1) カルビンーベンソンサイクルと共役して水から 水素イオン $\mathrm{H}^{+}$をりだし供給できること。

(2) カルビンーベンソンサイクルを駆動するに必要
な $\mathrm{CO}_{2}$ 固定用原料の 1 つ $\mathrm{NADPH}$ (式(4) ) と $\mathrm{CO}_{2}$ 固 定用エネルギー源 ATP（式(3)）を定常的に循環供給 できること

(3) カルビンーベンソンサイクル内でリブロース5 -リン酸 (Ru5P) を出発原料として式(5)から式(18)の 反応を実現するに必要なエネルギーを供給できること。

(4) カルビンーベンソンサイクルに $\mathrm{CO}_{2}$ と $\mathrm{H}_{2} \mathrm{O}$ を 定常的に取り組む仕組を有すること。

(5) カルビンーベンソンサイクルの生成物として系 外にブドウ糖を定常的に排出・眝蔵できること。

次章では上述の 5 つの条件を満たす光合成セラミク 又解媒の概念を提出し，その実現性について素材物性 学的ならびに素材文化学的に考慮する。

2. 光合成セラミクス解媒および光合成セラミ クス素子の概念とその実現性に関する素材 物性学的考察

本章では前述の光合成実現の 5 つの条件を満足する 光合成セラミクス触媒の設計について素材物性学 的 ${ }^{18,}$, 19) に検討する。そして, 光合成セラミクス触媒を 用いた光合成セラミクス素子の概念を提出する。

\section{1 光合成セラミクス触媒の設計について}

前述の 5 つの光合成実現の条件のうち(1)の “カルビ ンーベンソンサイクルと共役して水から水素イオン H+をとりだし供給できること”を満たすセラミクス 触媒について考察する。

水から水素ガス $\mathrm{H}_{2}$ およよび酸素ガス $\mathrm{O}_{2}$ を発生させ るに必要なエネルギーはそれぞれ $0.686 \mathrm{eV}$ および一 $0.571 \mathrm{eV}$ である。

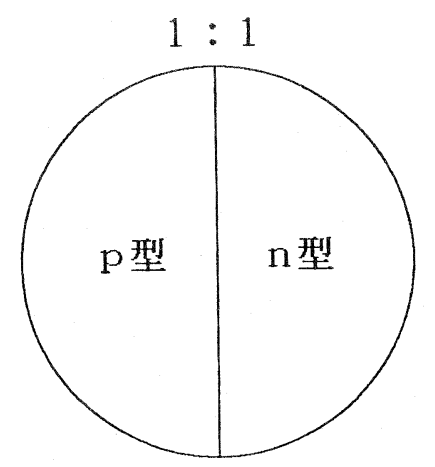

Fig. 6 The concept of $1 / 1$ type of pn-conjunction particle 
いま, Fig. 6 のような $\mathrm{p}$ 型部と $\mathrm{n}$ 型部の容積比 $1 / 1$ の pn 接合粒子 $\left(\mathrm{SnO}_{2}\right.$, 直径 $5 \mu \mathrm{m}, 1 / 1$ 型 $\mathrm{pn}$ 接合粒 子と呼ぶ）を考えてみよう。Fig. 7 には $\mathrm{SnO}_{2}$ の p 型 部と $\mathrm{n}$ 型部のそれぞれの電子エネルギー帯構造を示 してある。ここで両者を接合して pn 接合を構成した 場合， $\mathrm{n}$ 型側で水素ガス $\mathrm{H}_{2}$ が発生しない条件，つま り 型側の自由電子の準位が水素発生エネルギー準 位 $0.686 \mathrm{eV}$ よ低くなる条件は次式で与えられると指 摘できる。

$$
\mathrm{E}_{\mathrm{fn}}-\frac{\mathrm{E}_{\mathrm{fn}}+\mathrm{E}_{\mathrm{fp}}}{2}<(1.5-0.686) \mathrm{eV}
$$

一方, $\mathrm{p}$ 型側で酸素ガス $\mathrm{O}_{2}$ と水素イオン $2 \mathrm{H}^{+}$が発 生する条件, つまり $\mathrm{p}$ 型側の自由正孔の準位が酸素発 生エネルギー準位 $-0.571 \mathrm{eV}$ より低くなるとして,

$$
\frac{\mathrm{E}_{\mathrm{fn}}+\mathrm{E}_{\mathrm{fp}}}{2}-\mathrm{E}_{\mathrm{fp}}<(-0.571-(-1.5)) \mathrm{eV}
$$

したがって, 式(20)と式(1)とを同時に満たす条件は次式 で表わされることがわかる。

$1.624 \mathrm{eV}<\mathrm{E}_{\mathrm{fn}}-\mathrm{E}_{\mathrm{fp}}<1.858 \mathrm{eV}$

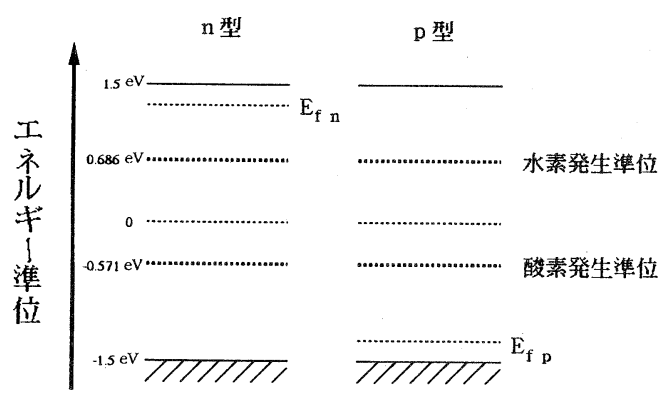

Fig. 7 Electron energy band structures of $\mathrm{p}$ type and $\mathrm{n}$ type of $\mathrm{SnO}_{2}$

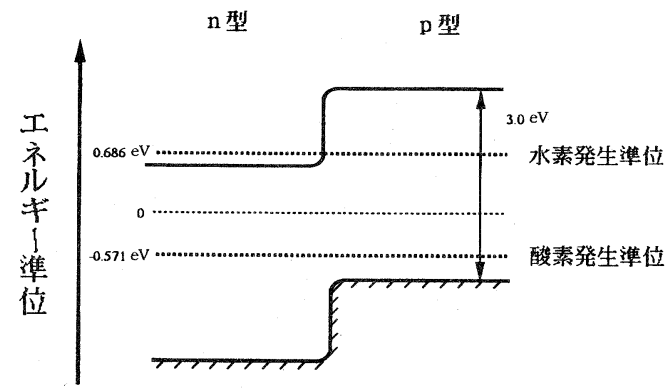

Fjg. 8 Electron energy band structure of 1/1type of pn-conjunction particle generating hydrogen ion $2 \mathrm{H}^{+}$and oxygen $1 / 2 \mathrm{O}_{2}$ $\mathrm{n}$ 型 $\quad \mathrm{p}$ 型

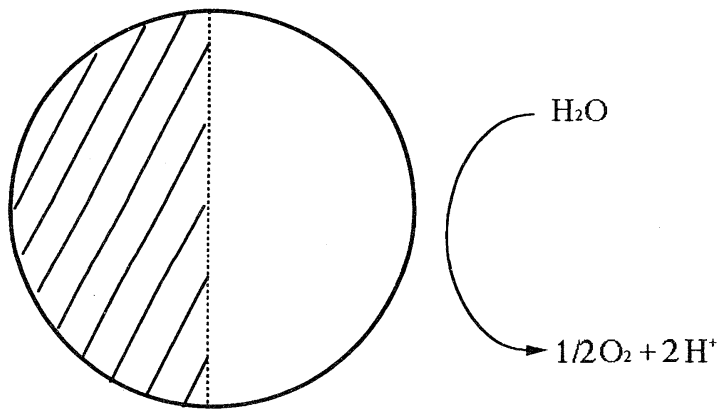

Fig. 9 1/1 type of pn-conjunction particle $\left(\mathrm{SnO}_{2}\right)$ generating hydrogen ion $2 \mathrm{H}^{+}$and oxygen $1 / 2 \mathrm{O}_{2}$

条件式(2) は不純物準位を制御することにより可能 である。その結果 Fig. 6 の1/1 型 pn 接合粒子の電子. エネルギー帯構造を Fig. 8 のようにすることができ る。これにより $1 / 1$ 型 pn 接合粒子は太陽エネルギー の照射をうけて Fig. 9 のように $\mathrm{p}$ 型側のみに酸素ガ ス $1 / 2 \mathrm{O}_{2}$ と水素イオンをつくりだすことができると指 摘できる。

つぎに, 光合成実現の条件(2)から(5)について検討し てみよう。条件(2)および(3)によれば明反応の式(3)，式 (4) と暗反応の式(5)加ら式(18)が太陽エネルギーにより起 こることが必要であることがわかる。これを実現させ るための幾何学的条件としてまず出発原材料としての 1 分子のリブロース -5 -リン酸 Ru $5 \mathrm{P}, 3$ 分子のア デノシン 5 - -ミリン酸 ATP, 3 分子の正リン酸 $\mathrm{Pi}$ および 2 分子の還元型ニコチン酸アミドアデニンジヌ クレオチドリン酸 NADPH が同一空間に共役して存 在しなければならないことがあげられる。これは Fig. 10 のような光合成セラミクス素子により達成される あのと考えられる。これによれば光合成セラミクス素 子は a）のように光合成部，原料供給部ならびに糖質 プロダクト取出部の 3 つの要素から構成されているこ とがわかる。ここで原料供給部，糖質プロダクト取出 部はそれぞれ条件(4)および(5)を満たすと指摘できる。

Fig. 10の 6) にはより具体的な光合成セラミクス 素子の概念図を，c）には光合成部の幾何学的概念図 を示してある。

さて，条件(2)および(3)について検討してみよう。式 


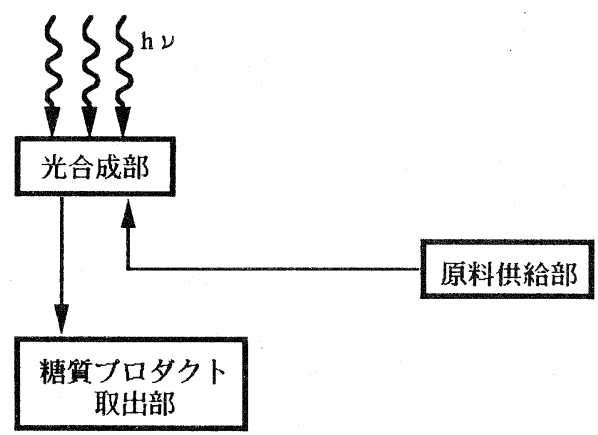

a ）光合成セラミクス素子の構造システム

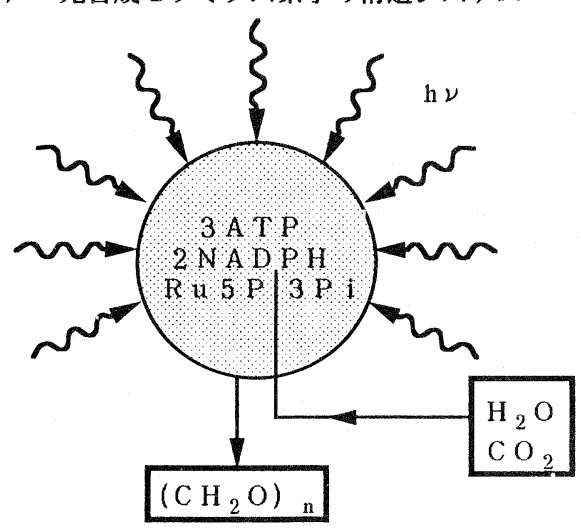

b ）光合成セラミクス素子の概念

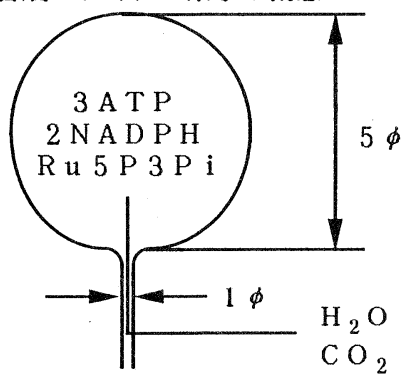

$\left(\mathrm{C} \mathrm{H}_{2} \mathrm{O}\right)_{\mathrm{n}}$

c）光合成セラミクス素子のディメンション

Fig. 10 The concept of photosynthesis ceramics element

(3)から式(18)の反応を起こすにはFig. 11 に示す太陽光 のエネルギー分布 $(0.5 \mathrm{eV} \sim 4 \mathrm{eV})$ を有効に取込む光 触媒セラミクスの最適な組合せを決定しなければなら ない。

本報では以上の観点から光触媒セラミクスとして エネルギーギャップがそれぞれ $3.8 \mathrm{eV}, 3.2 \mathrm{eV}, 2.6 \mathrm{eV}$, $2.05 \mathrm{eV}, 1.66 \mathrm{eV}$ および $1.26 \mathrm{eV}$ の $\mathrm{AlN}, \mathrm{SrTiO}_{3}$,

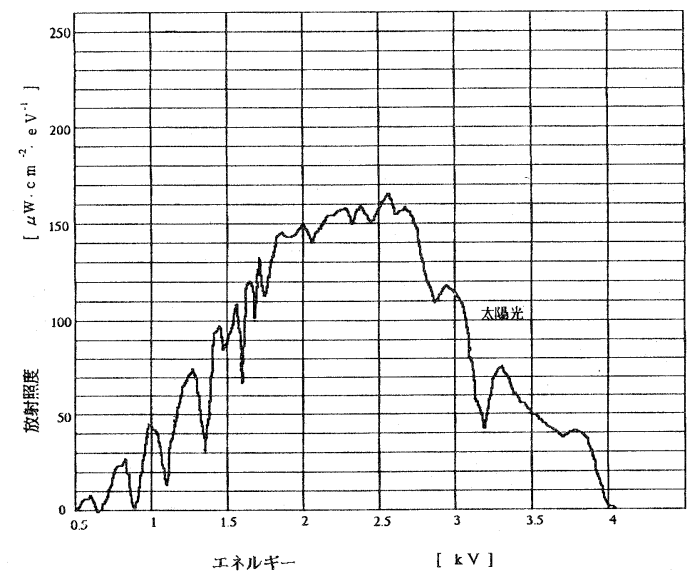

Fig. 11 The spectrum of the sunlight energy

$\mathrm{Sr}_{0.75} \mathrm{Ag}_{0.25} \mathrm{TiO}_{3}, \mathrm{GaSe}, \mathrm{GaTe}$ および $\mathrm{SnS}$ を選択す る。ただし, $\mathrm{Sr}_{0.75} \mathrm{Ag}_{0.25} \mathrm{TiO}_{3}$ のエネルギーギャップ2. $6 \mathrm{eV}$ は量子力学ならびに群論的手法を用いて求めた。 たとえば'19)，この組合せ（エネルギーギャップ $1.26 \mathrm{eV}$ 〜3.8eV）により太陽光のエネルギーを効率 $95 \%$ で取 込むことができる。

仮に太陽光を効率 $95 \%$ で取込んだとしても, 光触媒 セラミクス粒子をFig. 6 のような $1 / 1$ 型 pn 接合粒子 として使用すれば, 光合成反応に供給しうるエネルギー はFig. 12 のうに $0.1 \mathrm{eV}$ (または $-0.1 \mathrm{eV}$ ）程度の 低いものになる。折角太陽エネルギーから $3.8 \mathrm{eV}$ とい う高いエネルギーを折込んでも, 供給時に $0.1 \mathrm{eV}$ （ま たはー0.1eV）ではエルルギー光合成反応に有効に利 用できない。

この問題を克服するために Fig. 13 のような $\Phi / 1$ $\Phi$ 型 pn 接合粒子の概念を提出する。ただし $\Phi$ は p 接 合粒子中の $\mathrm{p}$ 型部の占める体積分率を意味している。

$\Phi / 1-\Phi$ 型 pn 接合粒子において $\mathrm{p}$ 型部と $\mathrm{n}$ 型部の それれぞれの体積が互いに相違している。そのため $\mathrm{p}$ $\mathrm{n}$ 接合時のキャリヤー移動に起因するフェルミ準位の 移動巾が相違する。つまり, フェルミ準位のキャリャー 濃度効果である。そのためFig. 14 に示す $\mathrm{p}$ 型ならび に $\mathrm{n}$ 型半導体を $\mathrm{pn}$ 接合した際のフェルミ準位を希望 值 $\mathrm{E}_{1}\left(\mathrm{E}_{\mathrm{fn}}>\mathrm{E}_{1}>\mathrm{E}_{\mathrm{fp}}\right)$ にする体積分率 $\Phi$ は次式によ りあとめられる。

$\frac{\mathrm{E}_{1}-\mathrm{E}_{\mathrm{fp}}}{\mathrm{E}_{\mathrm{fn}}-\mathrm{E}_{1}}=\frac{\ln \Phi^{-1}}{\ln (1-\Phi)^{-1}}$ (23) 

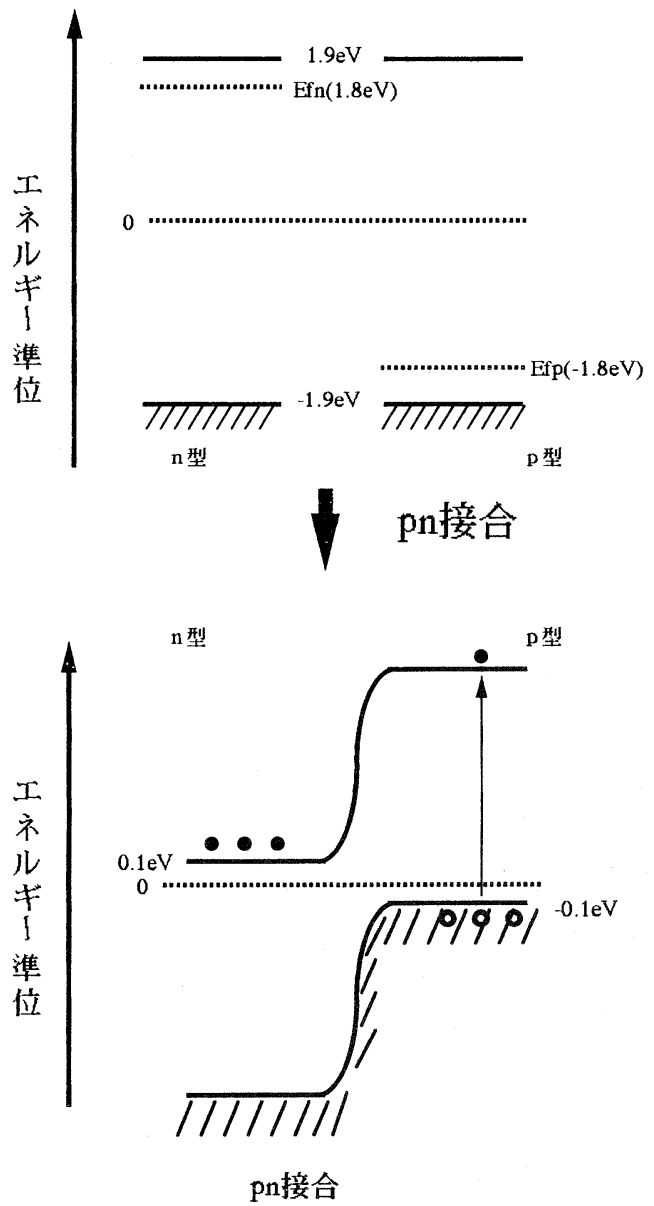

Fig. 12 Electron energy band structure of 1/1type of pn-conjunction particle (AIN)

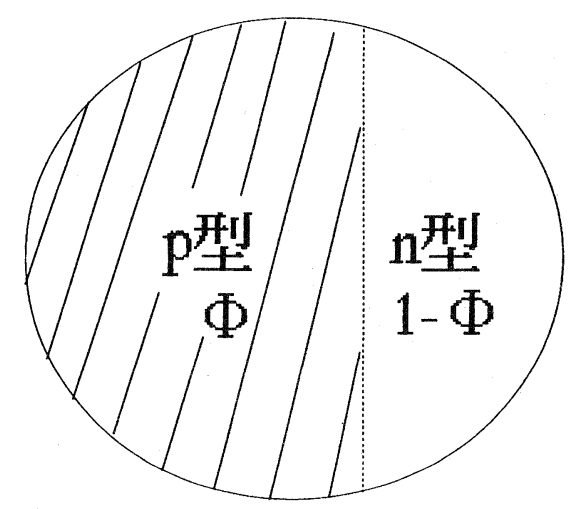

Fig. 13 The concept of $\Phi / 1-\Phi$ type of pn-conjunction particle

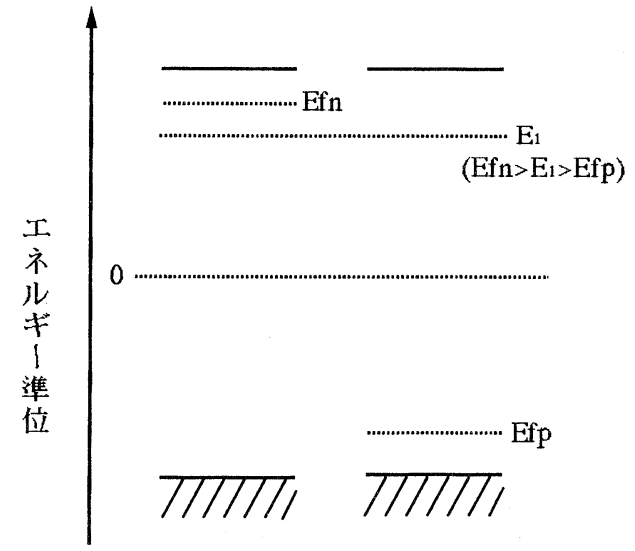

Fig. 14 The control concept of Fermi level $\mathrm{E}_{1}$ of $\Phi / 1-\Phi$ type of pn-conjunction particle

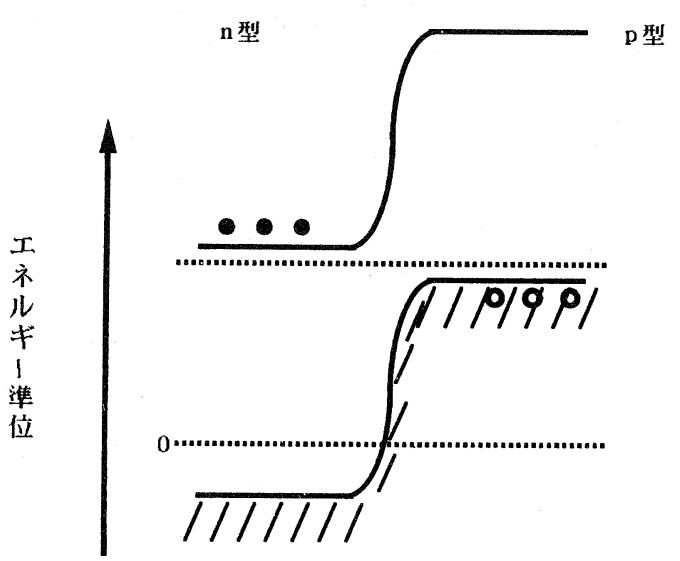

Fig. 15 Electron energy band structure of $\Phi /$ 1- $\Phi$ type of pn-conjunction particle

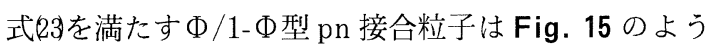
な電子エネルギー帯構造をもつ。これによれば $\mathrm{n}$ 型側 のみが光合成反応に有効なエネルギー $\mathrm{E}_{1}$ を供給でき ることがわかる。つまり, p 型側が不活性となるため 反応妨害（自由電子と自由正孔間）がなくなる。すな わち， $\Phi / 1-\Phi$ 型 pn 接合粒子は原理的に優れた触媒と して機能できることが指摘できる。

この手法の特徴は pn 接合時のフェルミ準位 $\mathrm{E}_{1}$ が $\mathrm{E}_{\mathrm{fn}}$ と $\mathrm{E}_{\mathrm{fp}}$ 間の任意の值に制御できる点にある。

さて,つぎに pn 接合時のフェルミ準位 $\mathrm{E}_{1}$ を前述 の領域外にも制御可能とするために， 
合粒子のФを一定して直径のみを変化する手法を導入 する。これによりキャリヤー濃度効果によるフェルミ 準位制御ができるからである。

ある基準直径の $\Phi / 1-\Phi$ 型 pn 接合粒子のフェルミ準 位 $\mathrm{E}_{1}$ とキャリヤー濃度 $\mathrm{n}$ との間には次式の関係があ る。

$\mathrm{E}_{1}=\tau \ln \mathrm{n}$

(24)

ここで, $\tau$ は特性エネルギー定数であり, あらかじめ 求めうる。

一方， Фを一定にして前述の $\Phi / 1-\Phi$ 型 pn 接合粒子 を任意の直径としたときのフェルミ準位 $\mathrm{E}_{1}{ }^{\prime}$ とキャリ ヤー濃度 n’との間にも同様に次式が成立する。

$\mathrm{E}_{1}^{\prime}=\tau \ln \mathrm{n}^{\prime}$

したがってフェルミ準位の変化 $\Delta \mathrm{E}_{1}\left(\equiv \mathrm{E}_{1}{ }^{\prime}-\mathrm{E}_{1}\right)$ は 次式のようになる。

$$
\Delta \mathrm{E}_{1}=\tau \ln \frac{\mathrm{n}^{\prime}}{\mathrm{n}}
$$

以上より，フェルミ準位を制御する 2 つの手法， 1 つは $\Phi / 1-\Phi$ 型 pn 接合粒子手法, 他の 1 つは $\Phi / 1-\Phi$ 型 $\mathrm{pn}$ 接合の直径制御手法が利用できることがわかる。

Table. 1 には前述の 2 つの手法を本報の 6 種類のセ ラミクスに対して適用し，設計した光合成セラミクス 触媒とそれぞれが光合成反応に供給するエネルギー值 を示してある。ただし，いゔれのセラミクスあ基準直 径を $5 \mu$ ，キャリヤー濃度 $\mathrm{n}$ を $10^{12} \mathrm{~cm}^{-3}$ とした。

これによれば $\mathrm{AlN}, \mathrm{SrTiO}_{3}, \mathrm{Sr}_{0.75} \mathrm{Ag}_{0.25} \mathrm{TiO}_{3}, \mathrm{Ga}$ $\mathrm{Se}, \mathrm{GaTe}$ および $\mathrm{SnS}$ は太陽光からそれぞれ $3.8 \mathrm{eV}$, $3.2 \mathrm{eV}, 2.6 \mathrm{eV}, 2.05 \mathrm{eV}, 1.66 \mathrm{eV}$ および $1.26 \mathrm{eV}$ のエ ネルギーを取込み，光合成反応へそれぞれ $1.8 \sim 3.2$ $\mathrm{eV}, 1.5 \sim 2.5 \mathrm{eV}, 1.2 \sim 2.0 \mathrm{eV}, 0.95 \sim 1.55 \mathrm{eV}, 0.73 \sim$

Table. 1 The particle design of photosynthesis ceramics catalysis

a）光合成セラミクス触媒 $\mathrm{AlN}$

\begin{tabular}{|c|c|c|c|c|c|c|c|c|}
\hline $\begin{array}{l}\text { 太陽光から取り込む } \\
\text { エネルギー }(\mathrm{eV})\end{array}$ & \multicolumn{8}{|c|}{$3.8 \mathrm{eV}$} \\
\hline$\Phi / 1-\Phi$ 型 pn 接合粒子 & \multicolumn{8}{|c|}{$\mathrm{p}$ 型部の占める体積分率 $\Phi=0.042$} \\
\hline $\begin{array}{l}\text { 光合成反応へ供給する } \\
\text { エネギー }(\mathrm{eV})\end{array}$ & $3.2 \mathrm{eV}$ & $3.0 \mathrm{eV}$ & $2.8 \mathrm{eV}$ & $2.6 \mathrm{eV}$ & $2.4 \mathrm{eV}$ & $2.2 \mathrm{eV}$ & $2.0 \mathrm{eV}$ & $1.8 \mathrm{eV}$ \\
\hline 粒子径 $(\mu)$ & $0.014 \mu$ & $0.032 \mu$ & $0.074 \mu$ & $0.17 \mu$ & $0.44 \mu$ & $0.92 \mu$ & $2.15 \mu$ & $5.0 \mu$ \\
\hline
\end{tabular}

b）光合成セラミクス触媒 $\mathrm{SrTiO}$

\begin{tabular}{|c|c|c|c|c|c|c|}
\hline $\begin{array}{l}\text { 太陽光から取り込む } \\
\text { エネルギー }(\mathrm{eV})\end{array}$ & \multicolumn{6}{|c|}{$3.2 \mathrm{eV}$} \\
\hline$\Phi / 1-\Phi$ 型 pn 接合粒子 & \multicolumn{6}{|c|}{$\mathrm{p}$ 型部の占める体積分率 $\Phi=0.049$} \\
\hline $\begin{array}{l}\text { 光合成反応へ供給する } \\
\text { エネルギー }(\mathrm{eV})\end{array}$ & $2.5 \mathrm{eV}$ & $2.3 \mathrm{eV}$ & $2.1 \mathrm{eV}$ & $1.9 \mathrm{eV}$ & $1.7 \mathrm{eV}$ & $1.5 \mathrm{eV}$ \\
\hline 粒子径（ $\mu$ ) & $0.032 \mu$ & $0.088 \mu$ & $0.24 \mu$ & $0.66 \mu$ & $1.81 \mu$ & $5.0 \mu$ \\
\hline
\end{tabular}

c）光合成セラミクス触媒 $\mathrm{Sr}_{0.75} \mathrm{Ag}_{0.25} \mathrm{TiO}_{3}$

\begin{tabular}{|c|c|c|c|c|c|}
\hline $\begin{array}{l}\text { 太陽光から取り込む } \\
\text { エネルギー }(\mathrm{eV})\end{array}$ & \multicolumn{5}{|c|}{$2.6 \mathrm{eV}$} \\
\hline$\Phi / 1-\Phi$ 型 pn 接合粒子 & \multicolumn{5}{|c|}{$\mathrm{p}$ 型部の占める体積分率 $\Phi=0.057$} \\
\hline $\begin{array}{l}\text { 光合成反応へ供給する } \\
\text { エネルギー }(\mathrm{eV})\end{array}$ & $2.0 \mathrm{eV}$ & $1.8 \mathrm{eV}$ & $1.6 \mathrm{eV}$ & $1.4 \mathrm{eV}$ & $1.2 \mathrm{eV}$ \\
\hline 粒子径（ $\mu)$ & $0.033 \mu$ & $0.11 \mu$ & $0.40 \mu$ & $1.43 \mu$ & $5.0 \mu$ \\
\hline
\end{tabular}


d）光合成セラミクス触媒 $\mathrm{GaSe}$

\begin{tabular}{|c|c|c|c|c|}
\hline $\begin{array}{l}\text { 太陽光から取り込む } \\
\text { エネルギー }(\mathrm{eV})\end{array}$ & \multicolumn{4}{|c|}{$2.05 \mathrm{eV}$} \\
\hline$\Phi / 1-\Phi$ 型 pn 接合粒子 & \multicolumn{4}{|c|}{$\mathrm{p}$ 型部の占める体積分率 $\Phi=0.067$} \\
\hline $\begin{array}{l}\text { 光合成反応へ供給する } \\
\text { エネルギー }(\mathrm{eV})\end{array}$ & $1.55 \mathrm{eV}$ & $1.35 \mathrm{eV}$ & $1.15 \mathrm{eV}$ & $0.95 \mathrm{eV}$ \\
\hline 粒子径（ $\mu ）$ & $0.04 \mu$ & $0.21 \mu$ & $1.03 \mu$ & $5.0 \quad \mu$ \\
\hline
\end{tabular}

e）光合成セラミクス触媒 $\mathrm{GaTe}$

\begin{tabular}{|c|c|c|c|}
\hline $\begin{array}{l}\text { 太陽光から取り込む } \\
\text { エネルギー }(\mathrm{eV})\end{array}$ & \multicolumn{3}{|c|}{$1.66 \mathrm{eV}$} \\
\hline$\Phi / 1-\Phi$ 型 pn 接合粒子 & \multicolumn{3}{|c|}{$\mathrm{p}$ 型部の占める体積分率 $\quad \Phi=0.075$} \\
\hline $\begin{array}{l}\text { 光合成反応へ供給する } \\
\text { エネルギー }(\mathrm{eV})\end{array}$ & $1.08 \mathrm{eV}$ & $0.88 \mathrm{eV}$ & $0.73 \mathrm{eV}$ \\
\hline 粒子径（ $\mu ）$ & $0.13 \mu$ & $1.06 \mu$ & $5.0 \mu$ \\
\hline
\end{tabular}

f）光合成セラミクス触媒 $\operatorname{SnS}$

\begin{tabular}{|c|c|c|c|}
\hline $\begin{array}{l}\text { 太陽光から取り込む } \\
\text { エネルギー }(\mathrm{eV})\end{array}$ & \multicolumn{3}{|c|}{$1.26 \mathrm{eV}$} \\
\hline$\Phi / 1-\Phi$ 型 pn 接合粒子 & \multicolumn{3}{|c|}{$\mathrm{p}$ 型部の占める体積分率 $\quad \Phi=0.099$} \\
\hline $\begin{array}{l}\text { 光合成反応へ供給する } \\
\text { エネルギー }(\mathrm{eV})\end{array}$ & $0.78 \mathrm{eV}$ & $0.68 \mathrm{eV}$ & $0.53 \mathrm{eV}$ \\
\hline 粒子径（ $\mu$ ) & $0.13 \mu$ & $0.56 \mu$ & $5.0 \mu$ \\
\hline
\end{tabular}

$1.08 \mathrm{eV}$ おび0.53〜0.78eV のエネルギーを自由電子 をキャリヤーとして供給できることを意味している。 このことはまた前述の 6 種類のセラミクス粒子を表面 積基準でそれぞれ一様になるよう秤量・調合すれば， 太陽光エネルギーの95\%を取込み (Fig. 16 の斜線部), それをFig. 16 の実線により示される分布をもつエネ ルギーへと変換できることがわかる。この変換エネル ギーは，太陽光エネルギーの $88 \%$ に相当し光合成反応 に有効に利用される。これにより条件(2)および(3)が達 成できる。

所定量の出発原材料 Ru5P, 2NADPH, 3ATPおよ び 3Pi を封入した Fig. 10 c）の光合成セラミクス素 子により条件(2)抢よび(3)は実現される。

\section{2 光合成セラミクス素子を用いた光合成システ ムに関する素材文化学的考察}

本章では本報で提出した光合成セラミクス素子を用
いた光合成システムについて素材文化学的 ${ }^{20)}$ に考察 する。

光合成システムは基本的にはFig. 10 c）のような 光合成素子を 2 次元的に配列した葉状面を主要部とす る Fig. 17 a）の構造となるものと考えられる。これ によれば光合成システムは一枚の木の葉のような形で, 太陽光エネルギーを取込む葉状部, $\mathrm{H}_{2} \mathrm{O}, \mathrm{CO}_{2}$ 供給部, 光合成システムを支持する主軸部および糖質プロダク 卜貯蔵部の 4 要素から構成されていることがわかる。 そして, 光合成システムの戸外での配置はFig. 17 b) のようになるものと予想される。

人間一人の一日あたりの糖質摂取量 $250 \mathrm{~g}$ を光合成 するに必要な葉状面積 A について検討してみよう。

さて, 緑色植物の光合成の太陽光エネルギー利用比 $\phi_{0}$ は次式で定義される。 


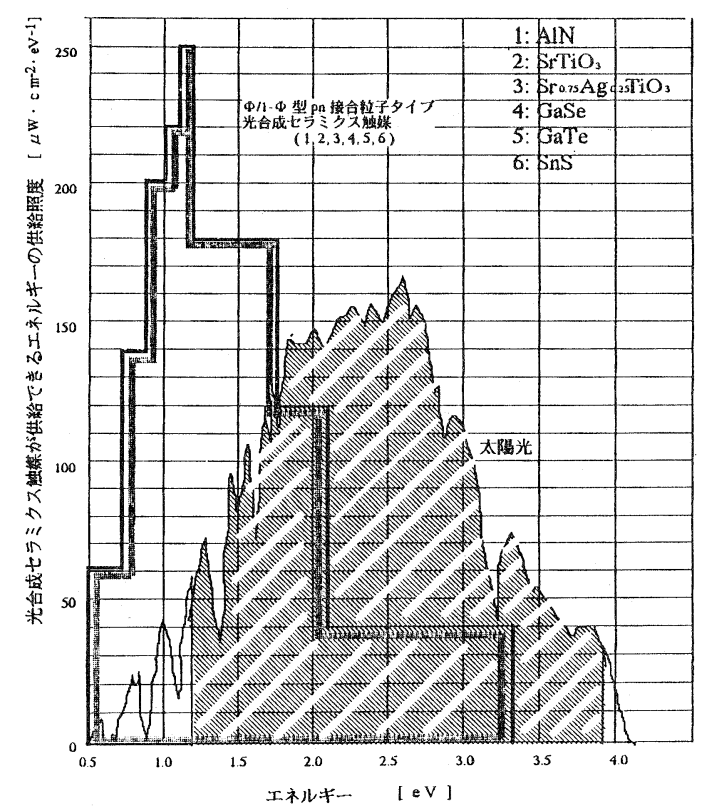

Fig. 16 The take in energy and the supply energy of $\Phi / 1-\Phi$ type of pn-conjunction photosynthesijs ceramics catalysis particle
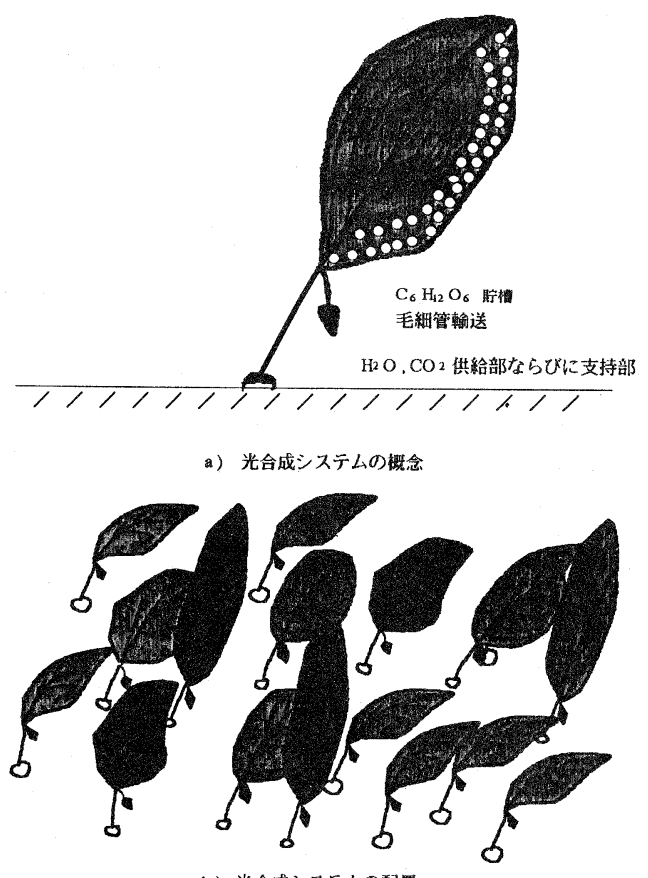

b) 光合成システムの配植

Fig. 17 The concept diagram of photosynthesis system using photosynthesis element

$$
\phi_{0}=\frac{\text { 光合成に用いられるエネルギー }}{\text { 吸収されたエネルギー }} \times 100(\%)
$$

測定結果によれば，利用比 $\phi_{0}$ は赤色光（主波長660 $\mathrm{nm}$ ）に対して $59 \%$, 緑色光（主波長 $546 \mathrm{~nm}$ ）に対し て44\%抄よび青色光（主波長 $436 \mathrm{~nm}$ ）に対して $38 \%$ で ある。これらの值を用いて 1 モルの $\mathrm{CO}_{2}$ を同化する に必要な光量子数をむとめると赤色光, 緑色光拉よび 青色光に対してそれぞれ 4.1 モル光量子， 4.3 モル光 量子抢よび 5.1 モル光量子となる。したがって，1 分 子の $\mathrm{CO}_{2}$ を同化するために 4.5 個の光量子が必要であ ると考えることができる。

ここで，1日の照射時間を 7 時間，利用比 $\phi_{0}$ を緑 色植物のそれの 5 分の 1 の $5 \%$ として光合成システム が 1 日あたり糖質分 $250 \mathrm{~g}$ を合成するに必要な葉状面 積 $\mathrm{A}$ は $1.2 \mathrm{~m}^{2}$ と指摘できる。

\section{結言}

本報においては，総合的知識に立脚した新しい工学 の学問体系を確立するという観点から, 近未来におけ る人類の食糧問題を考察し, それが短期的でかつ緊迫 した問題であることを指摘した。そして，この食糧問 題を克服するための支援として光合成システムの概念 を提出し，その実現可能性について素材物性学的なら びに素材文化学的に考察し以下の知見を得た。

1）植物の光合成メカニズムの素材物性学的特徴を

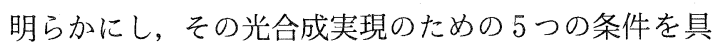
体的に示した。

2）1）の光合成実現のための 5 つの条件を $\Phi / 1-\Phi$ 型 pn 接合粒子の概念により満たすことができること を明らかにした。

3）光合成触媒セラミクスの組合せとして AlN,

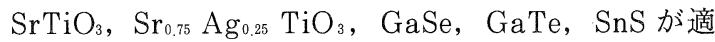
当であることを指摘し，それぞれの光合成触媒セラミ クスに対して粒子設計を具体的に示した。

4) $\mathrm{CO}_{2}, \mathrm{H}_{2} \mathrm{O}$ から糖質プロダクトを光合成するに 必要な光合成セラミクス素子ならびに光合成システム の概念を提出した。

5）人間一人の一日あたりの糖質摂取量 $250 \mathrm{~g}$ を合 成するに必要な光合成システムの葉状面積が $1.2 \mathrm{~m}^{2}$ で あることを指摘した。

以上，本報においていては光合成システムの概念を 
素材文化学的に提出したが, 今後さらにその実現可能 性について系統的に検討することが望まれる。

\section{引用文献}

1）デカルト；世界の思想 1 “近代思想のめざめ”, 167 〜204（河出書房新社，1965)

2）ミル；世界の思想 6 “イギリスの近代政治思想”, 173 399 (河出書房新社, 1965)

3）世界大百科事典, 14-74（平凡社, 1993)

4) Priestly, J. ; 世界大百科事典, 25-164 (平凡社, 1993)

5) Ingenhousy, J. ; 世界大百科事典, 3-164（平凡 社, 1993)

6) 藤 茂宏; 光合成, $1 \sim 155$ (東京大学出版会, 1983)

7）石田政宏 ; 葉緑体の分子生物学, 1 120（東京大 学出版会, 1987)

8）ハーバート・G.・ベイカー（阪本, 福田訳); 植 物之文明, 1 ～268（東京大学出版会, 1979)
9.) 紫田承二, 山崎幹夫; 植物成分の生合成, 1 213 (東京化学同人, 1977)

10) Hill, R. et al.; Nature, 190, 136 (1960)

11）西田晃二郎; 光合成の暗反応, $1 \sim 108$ (東京大学 出版会, 1986)

12) Calvin, M., et al. ; Experimentia, 8, 445 (1952)

13) Bassham, J.A., et al. ; J.Am. Chem. Soc., 76, 92 (1954)

14）松中昭一, 他; 雑草研究, 22, 133 (1975)

15) Decker, J. P. ; Plant Physiol., 30, 82 (1955)

16) Decker, J.P. ; J. Sol. Ene. Sci. Eng., 1, 30 (1957)

17）村田吉男, 他; 植物生理学 2, 150 （朝倉書店, 1981)

18）牧野和孝; エレクトロセラミクス素材物性学, 1 207（日刊工業新聞社，1992）

19）牧野和孝; エレクトロセラミクス素材設計学, 1 ２32（日刊工業新聞社，1992）

20）牧野和孝; 素材物性学雑誌, Vol. 10, No.1, 32 (1997) 